\title{
Strategies for Sustainable Use of Indigenous Cattle Genetic Resources in Southern Africa
}

\author{
Cletos Mapiye ${ }^{1, *}$, Obert C. Chikwanha ${ }^{1}$, Michael Chimonyo ${ }^{2}$ and Kennedy Dzama ${ }^{1}$ \\ 1 Department of Animal Sciences, Faculty of AgriSciences, Stellenbosch University, Private Bag X1, \\ Matieland 7602, South Africa; occhikwanha@yahoo.com (O.C.C.); kdzama@sun.ac.za (K.D.) \\ 2 Animal and Poultry Science, School of Agricultural, Earth and Environmental Sciences, University of \\ KwaZulu-Natal, P/Bag X 01, Scottsville 3209, Pietermaritzburg, South Africa; chimonyo@ukzn.ac.za \\ * Correspondence: cmapiye@sun.ac.za; Tel.: +27-218-082-640
}

Received: 14 October 2019; Accepted: 5 November 2019; Published: 12 November 2019

\begin{abstract}
Indigenous cattle breeds are the most important livestock species in the Southern African Development Community (SADC) region owing to their role in human food, nutrition, income, and social security. Despite the role of these breeds in the household and national economies, they are currently underutilised, their productivity remains low, and populations are faced with extinction. In addition, there are insufficient measures taken to secure their present and future value. The current review highlights strategies for sustainable use of indigenous cattle genetic resources in the region, including the use of novel production and marketing practices, women and youth empowerment, and development of the appropriate capacity building, legislative, and policy structures. At present, the lack of coordination among the different stakeholders still poses a challenge to the implementation of these strategies. To this end, partnerships, collaboration, and stakeholders' participation are recommended to effectively implement strategies for sustainable use of indigenous cattle breeds.
\end{abstract}

Keywords: food security; indigenous cattle; genetic diversity; SADC; sustainable use

\section{Introduction}

The Southern African Development Community (SADC) is a Regional Economic Community comprising 16 Member States; Angola, Botswana, Comoros, Democratic Republic of Congo, Eswatini, Lesotho, Madagascar, Malawi, Mauritius, Mozambique, Namibia, Seychelles, South Africa, Tanzania, Zambia, and Zimbabwe. The SADC region is home to over 64 million cattle, of which about $75 \%$ are raised on rangelands in extensive production systems [1]. Indigenous cattle breeds, Bos taurus africanus (e.g., Nguni, Tuli and Tswana) and Bos indicus (e.g., Malawi Zebu and Angoni) [2] are the most important as they are capable of meeting the food, income, and cultural needs of the poverty-stricken smallholder farmers in the region. Through centuries of natural selection, the indigenous cattle have adapted to the local environment as evidenced by their tolerance to heat stress, resistance to endemic diseases and parasites, and ability to thrive during long periods of feed and water shortages [3-5]. They are also resilient to the socioeconomic crises experienced in the region. Indigenous cattle breeds produce high quality products under smallholder farming systems, including meat and milk with unique organoleptic qualities $[3,6,7]$, long, thick, and beautifully shaped horns, multi-coloured skins, and their good-looking and durable by-products, such as Nguni hides [8], Nguni-derived ottoman [9], Ankole horn tumblers [10], and Ankole horn-bracelets [11].

Indigenous cattle breeds are currently underutilised in the commercial sector largely due to their slow growth rates and low carcass yields [1,12]. However, these are adaptive traits that help them survive harsh climatic conditions, such as feed and water scarcity. Such adaptive traits should be considered in order to ensure equitable and sustainable sharing of benefits derived from the cattle, 
and also when developing strategies to respond to climate change as well as future policy and regulatory measures. Sustainable use of indigenous breeds adapted to the harsh local environmental (i.e., feed and water scarcity and extreme temperatures) and socioeconomic conditions are unlikely to be optimal without addressing non-genetic factors affecting the cattle industry, including market changes and movements of germplasm frequently involving the importation of exotic breeds [5]. Knowledge of population structure and genetic diversity among indigenous cattle breeds is also important for genetic improvement, and their subsequent conservation and sustainable use $[7,13]$. The current paper reviews the genetic diversity of indigenous cattle in the SADC region, and provides strategies for long-term sustainable use of indigenous cattle genetic resources.

\section{Genetic Diversity of Cattle Breeds in Southern Africa}

In the SADC region, the indigenous cattle breeds are classified as either Zebu (B. indicus) or Sanga (B. taurus africanus, an admixture of B. indicus and B. taurus). The Zebu are phenotypically distinguishable by their thoracic humps compared to the Sanga, which are characterised by their cervico-thoracic humps $[2,4,14]$. There is also a new cattle type called "Zenga", which is a cross between the Zebu and Sanga (e.g., Bovines of Tete, Blukwa, Sukuma) [3,14,15]. Nyamushamba et al. [7] argued that genetic distinctiveness between indigenous cattle breeds in the SADC is largely unknown, with some populations aptly referred to as ecotypes. Overall, there are about 40 breeds and/or ecotypes of indigenous cattle in the SADC region [14]. Table 1 lists some of the indigenous breeds/ecotypes found in the SADC region. Often, one breed may be known by different names and equally, two breeds may be known by the same name depending on the geographical locations $[16,17]$. For example, the 'Landim' in Mozambique is an ecotype of the Nguni type of cattle found in Swaziland and South Africa [18]. Similarly, in South Africa, the Bartlow, Makhathini, Pedi, Shangaan, and Venda are ecotypes within the Nguni breed [17]. There is scant information on the genetic diversity of indigenous cattle populations within the SADC region, especially on the extent to which their descendent gene pools have been perturbed by introgression and migration [19]. There are, however, limited studies, which have been conducted on the genetic diversity of indigenous cattle breeds in the region. South Africa leads in this field owing to advanced sustainable programmes of recording for genetic improvement of cattle breeds [15,17,20-22]. Few studies have been conducted in Zimbabwe [23], Mozambique [18,19], and Tanzania [16].

The genetic diversity among South African indigenous cattle breeds has been assessed using DNA markers (i.e., microsatellites and single nucleotide polymorphism) [24]. Makina et al. [20] reported that the average genetic distance was lowest among indigenous (i.e., Afrikaner, Nguni, and Drakensberger) and locally developed (i.e., Bonsmara) breeds, and greatest between indigenous and exotic cattle breeds (i.e., Angus and Holstein). Sanarana et al. [17] observed a closer relationship in terms of the genetic distances between Makhathini, Pedi, and Shangaan ecotypes followed by Shangaan and Venda ecotypes of the Nguni breed. The observed small genetic differentiation $\left(F_{\mathrm{ST}}=4.8 \%\right)$ is a clear indication of admixture among these ecotypes with clear separation where a Nguni population was subjected to selection linked to the geographic area and specific ethnic groups [17]. In Zimbabwe, Gororo et al. [23], using microsatellite markers, observed significant variation between the Mashona, Nkone, and Tuli and concluded that they are distinct breeds. Kotze et al. [18] and Bessa et al. [19] showed that the Bovines of Tete, Angone, and Landim of Mozambique are genetically related with the former being an admixture between the latter two. Bessa et al. [19] further hypothesised that the Bovines of Tete could be a result of crossbreeding between the Angone and Mashona due to the close geographic proximity between the parental breeds. Similar findings were reported by Gwakisa, Kemp, and Teale [16] among the Tanzanian indigenous breeds (i.e., Boran, Mpwapwa, and Tanganyika Short-horned Zebu).

Genetic diversity forms the core for future cattle farming and is the foundation of adaptive traits of cattle in their own production environments [25]. It is also important for assigning cattle to their population of origin [15]. Furthermore, the diversity among cattle acts as a reservoir for genetic 
variation to ensure that future market demands are met through selection [21]. Humans have decreased the populations of indigenous cattle and have also caused serious loss of their genetic diversity [26,27]. The purity, productivity and population sizes of indigenous cattle in Africa have been under threat over the past four centuries, with $20 \%$ of the breeds already extinct, $32 \%$ in danger of extinction, and many at risk of extinction $[3,14]$. In South Africa, for example, pure Nguni cattle numbers declined from about 1.8 million in 1992 to 0.1 million in 2003 [28]. Some indigenous breeds or ecotypes in South Africa such as Nkone, Pedi, and Shangaan that have population sizes of less than 1000 animals and are critically endangered [7]. These low numbers are a cause for concern as their effective population is far below a threshold that would ensure sustainable use of these breeds [29].

Table 1. Indigenous cattle breeds found in the SADC region.

\begin{tabular}{|c|c|}
\hline Country & Breeds \\
\hline Angola & Barra do Cuanzo, Barotse, Humbi, Ovambo, Porto-Amboim, Ankole \\
\hline Botswana & Tswana \\
\hline Comoros & $\mathrm{ND}^{1}$ \\
\hline Democratic Republic of Congo & $\begin{array}{c}\text { Alur (Nioka, Blukwa), Bahima, Bashi, Lagune, N’Dama, Ruzizi, } \\
\text { Ankole-Watusi }\end{array}$ \\
\hline Eswatini (Swaziland) & Nguni, Drakensberger \\
\hline Lesotho & Basotho \\
\hline Madagascar & $\begin{array}{c}\text { Baria, Madagascar Zebu, Manjan'i Boina, Rana (Omby Rana), } \\
\text { Renitllo }\end{array}$ \\
\hline Malawi & Malawi Zebu \\
\hline Mauritius & $\mathrm{ND}^{1}$ \\
\hline Mozambique & Angonia (Angone), Bovines of Tete, Ladim \\
\hline Namibia & Caprivi, Damara (Herero), Kaokoveld, Okavango, Ovambo \\
\hline Seychelles & $\mathrm{ND}^{1}$ \\
\hline South Africa & $\begin{array}{l}\text { Afrikaner, Bonsmara, Drakensberger, Nguni, Pedi, Shangan } \\
\text { Mkalama Dun, Mpwapwa, Pare, Sukuma (Tinde), Renitllo, }\end{array}$ \\
\hline Tanzania & $\begin{array}{c}\text { Tanganyika Short-horned Zebu (Iringa red, Masai grey, Singida } \\
\text { white, Mbullu, dwarf Chagga), Tarime (Shashi), Ugogo Grey, } \\
\text { Ankole-Watusi, Zanzibar Zebu }\end{array}$ \\
\hline Zambia & Angoni, Barotse, Tonga \\
\hline Zimbabwe & Mashona, Nkone, Tonga, Tuli \\
\hline
\end{tabular}

Adapted from Gwakisa, Kemp, and Teale [16] and Rege [14]. ${ }^{1}$ ND—No data. SADC—Southern African Development Community.

The prevailing loss of genetic resources concerns not only the extinction of indigenous cattle breeds, but also the loss of genetic diversity within breeds [29]. Social and economic pressures have exposed at least 1000 livestock breeds to the risk of extinction [30], with cattle having the highest number of extinct breeds [27]. The main causes of genetic erosion of indigenous cattle breeds is their marginalisation in favour of elite exotic cattle breeding lines and the subsequent unstructured crossbreeding [14,31,32]. Although crossbreeding programmes between exotic and indigenous breeds were intended to improve biological and economic efficiency [33], their unstructured nature has produced non-descript crossbred cattle that are currently dominant in most smallholder farming areas in Southern Africa [7,33]. In South Africa, non-descript crossbred cattle now constitute more than two thirds of the smallholder herd [34]. Crossbreeding programmes have neglected climate change in their objectives. Therefore, to cope with climate change, selection based on productivity will lead to animals and populations that are not only effective in using the natural resources optimally but are adapted to survive in punitive environments. This will favour the indigenous breeds, thereby assisting in increasing productivity in these environments [35].

Genetic diversity losses are aggravated by focusing on specialised production systems, failure to evaluate local breeds, and by inappropriate breed replacement, especially in post-disaster rehabilitation programmes [27], involving the introduction of breeds which are not adapted to local production environments. For example, most breeding programmes are implemented in isolation without a built-in 
and continued consideration for the smallholder farmers' objectives [36]. Such programmes cover the initial costs, yet the long-term risks and consequences are borne by the farmers [33]. Other contributory factors include a shift to profit-oriented farming, shrinkage of grazing lands and development of irrelevant policies with a bias towards the commercial production system. Lack of active involvement of key stakeholders and/or the poor coordination among them $[27,37,38]$, and the lack of socioeconomic valuation of cattle genetic resources [33], climate change, and diversifying market demands [32] all contribute to loss of cattle genetic resources.

The continuous dilution and loss of indigenous cattle germplasm in Southern Africa is a cause for concern as cattle are an integral contributor of food, nutrition, and income in the region [37]. Despite the fact that exotic and non-descript breeds are popular and can be preferred, the adaptation, cultural benefits, and traditional knowledge systems related to keeping indigenous breeds cannot be easily replaced [32]. High genetic diversity among indigenous cattle enables farmers to select stock or develop new breeds in response to changing climates, new or resurgent disease threats, new knowledge of human nutritional requirements, and changing market conditions, social, and cultural needs. The benefits would be permanently lost in the case of extinction of the indigenous breeds. It is, therefore, imperative to catalogue and take conservation measures to avoid an irremediable loss to this reservoir for genetic diversity and allow sustainable use of cattle breeds in their local environments [20,21].

\section{Conservation of Cattle Genetic Resources in Southern Africa}

Conservation of indigenous cattle breeds is critical for reversing the unprecedented loss of diversity and ensuring security of cattle genetic resources for economic, ecological, and social benefits in the region. For the past two decades, Southern African countries have initiated programs to sustainably conserve cattle genetic resources but have often been limited at the policy level [27]. Cattle genetic resources have been conserved in situ (i.e., as live populations in their adaptive environments), ex situ in vivo (i.e., as live populations away from the habitat), and ex situ in vitro (i.e., storage of germplasm in the form of semen, ova, embryos, or tissues) [7,39]. Overall, in the SADC region, farmers, breeders, breed societies, government research institutes, and universities have been involved in in situ conservation of cattle genetic resources. According to Nyamushamba et al. [7] and Gororo et al. [23], the cattle populations of Mashona, Nkone, and Tuli breeds are kept at various research institutes in Zimbabwe (i.e., Henderson, Matopos, Makoholi, and Grasslands). In Malawi and Mozambique, the Malawi Zebu and the Landim are reared at Chitedze Agricultural Research Station and the Institute of Animal Production, respectively [7,18]. Regionally, South Africa seems to be leading the pack in terms of in situ conservation. For example, pure herds of Bonsmara, Afrikaner, and Nguni are kept at government research centres (e.g., Mara Research Institute and Agricultural Research Council-Animal Production Institute), University farms (e.g., University of Fort Hare Honeydale farm), and many South African stud farms $[17,20,40]$. For most of the SADC countries, there is limited, if any, public data on the ex situ conservation programmes as it is cost-intensive [27,33]. More work still needs to be done in terms of ex situ conservation as some breeds are critically endangered with others on the brink of extinction [27].

Despite efforts put in place to characterise and conserve indigenous cattle in the SADC region [3,7], the owners of these breeds have not been deriving optimum benefits and livelihoods from these genetic resources [7,41]. It is important to document key strategies for sustainable use of indigenous cattle genetic resources adapted to the challenges that are inherent in the marginal areas where the majority of resource-limited cattle owners reside. Sustainable use of animal genetic resources is defined as the use of components of animal diversity in a way and at a rate that does not lead to its decline in the long-term, thereby maintaining its potential to meet the needs and aspirations of present and future generations [42]. 


\section{Strategies for Sustainable Use of Cattle Genetic Resources in Southern Africa}

\subsection{Cattle Breeding and Reproduction Strategies}

The first step toward sustainable use of cattle genetic resources in the region is to control the continuous dilution of indigenous breeds through the establishment of structured breeding programmes [3]. Innovative breeding programmes, including community-based breeding programmes (CBBP), should be considered for smallholder cattle farmers [43]. The success of CBBP has been hindered by the centralisation of the schemes by governments or research institutes without the farmers' active participation $[38,43,44]$. Stakeholders' participatory approaches to CBBP policy formulation addressing local needs are key to success [36,44]. To avoid further introduction of exotic germplasm into communities, indigenous sires must be selected at the community level for use in these programmes and all unselected bulls should be castrated or sold [45]. To reduce inbreeding within the herds, rotation of bulls between communities could be practised [37]. Such in situ conservation with sustainable use of indigenous cattle should allow them to continuously evolve and reproduce, and produce while adapting to the changing environment [46]. Given the multiple roles of cattle and multiple objectives of smallholder farmers [7], it is important to develop multiple trait selection indices for simultaneous improvement of traits of economic importance.

The identification of breeding objectives in smallholder areas should consider market and non-market interests of farmers. To improve production through crossing with exotic breeds, careful selection and judicious crossbreeding of indigenous breeds with unique traits in combination with relevant biotechnologies may improve sustainable use of cattle genetic resources in the region [46]. Terminal offspring should not be used in the breeding programme but sold for economic benefits to the farmers. Alternatively, if they are required for draught power, the bulls must be castrated to avoid inbreeding. The exploitation of indigenous breeds, in terms of hardiness and disease tolerance, while upgrading productivity from the superior, yet more fragile and disease susceptible improved breeds can renew interest in indigenous breeds in the participating communities. There is also potential for multiplier effects [39].

Despite the long-term progress made through conventional breeding, the use of modern assisted reproductive technologies (i.e., artificial insemination, multiple ovulation and embryo transfer, cryopreservation, and cloning), by which the productive exotic breeds have expanded, may also contribute to the conservation of local breeds [12]. Gene editing is not ethically accepted by many countries today [47], but offers a faster, cheaper, healthier, more-efficient, and sustainable animal production opportunity compared to conventional breeding programs [48,49]. The technology holds potential for cattle production in future, but researchers must be aware of its challenges when applying it at a large-scale and integration in breeding schemes $[47,48,50]$. The success and future application of this novel technology will be largely influenced by decisions around the regulatory framework and governance of genome editing for food animals [49].

To avoid extinction of indigenous breeds, the SADC region should also establish regional ex situ gene banks for preservation and use of cattle genetic resources [27]. The use of gene banks could be done at the regional level since the majority of the individual countries have neither the resources nor the capacity to start such an initiative. Some countries in the region have well developed public and private institutions, which can be used for in situ conservation herds [51]. Leroy et al. [52] recommended that the success of a breeding scheme should be compatible with the breeding objective of the farming system. It was further suggested that there should be greater collaboration with smallholder farmers complemented with market incentives and institutional support services [53]. Sustainable use of the indigenous breeds may lower external inputs like feeding and health care, and thus improve the profits gained by smallholder producers. This will consequently contribute towards achieving sustainable food and nutrition security for the SADC region. Raising awareness among cattle farmers and policy-makers about the uniqueness of the indigenous breeds, importance of 
maintaining purity of the breeds, and potential roles of the breeds in climate change adaptation could further promote utilisation of indigenous animal genetic resources $[54,55]$.

\subsection{Cattle Feeding Strategies}

The majority of indigenous cattle owned by smallholder farmers are raised entirely on communal rangelands. The productivity of communal rangelands is challenged by climate change and degradation due to uncontrolled grazing, encroachment of indigenous woody plants, and the spread of invasive alien plants [56]. In that context, it is important to develop and implement innovative community-based rangeland management and forage conservation technologies [57]. Inclusion of indigenous woody and alien invasive plant seed, pod, and/or leaf meal in home-based formulation of beef cattle diets should also be considered. Alien invasive plants such as the Acacia species have been introduced in some SADC countries for the provision of timber and tannin extracts [58], but have encroached into rangelands in the smallholder areas [56]. Vachellia karroo and Vachellia polyacantha indigenous invasive species have been incorporated as protein supplements in beef diets and improved growth performance and carcass quality of indigenous cattle $[59,60]$. Such locally based strategies can increase the rangeland productivity and adaptive capacity for the owners of indigenous cattle genetic resources [57]. Initiatives such as the cattle custom feeding programme implemented by the National Agricultural Marketing Council (NAMC) of South Africa [61] can also result in sustainable use of cattle genetic resources. Under the NAMC programme, producers voluntarily send their cattle to a communal custom feeding centre, where they are managed and fed a finisher diet for four months prior to marketing.

Cattle on rangelands or custom feedlots can be supplemented with novel and alternative feeds, including locally available plant residues and by-products (PBP) from agro-industrial processes [62-64]. Compared to grazing exotic cattle breeds, indigenous breeds are a significant source of anthropogenic greenhouse gas emissions (i.e., $\mathrm{CH}_{4}$ and $\mathrm{NO}_{2}$ ) because of their low performance based on beef and milk yield traits [65,66]. In that context, selection of high-performing indigenous breeds [67] combined with use of bioactive-rich PBP may improve their biological and economic efficiencies, and consequently lower greenhouse emissions. Bioactive-rich PBP are capable of manipulating microbial ecosystems and fermentation kinetics of ruminants $[68,69]$. This subsequently improves rumen fermentation, reduces loss of feed energy, and enhances animal health and production, shelf-life, and fatty profile of beef $[62,70]$. Although the adaptation to climate change is necessary to safeguard food and nutrition security, whilst ensuring sustainable livelihoods of rural farmers, mitigation of enteric greenhouse gas emissions can lessen the extent of climate change and future needs for adaptation [71]. Further research is warranted to provide more evidence to justify development of feed innovations and policy intervention strategies that will promote wide adoption of PBP for sustainable beef production from the indigenous cattle breeds. Provision of balanced diets does not only unlock the genetic potential of indigenous cattle breeds but can also improve their health status.

\subsection{Cattle Health Management Strategies}

Despite indigenous cattle adaptation to local climatic and socio-economic environments, diseases and parasites still cause irremediable socio-economic impacts on productivity in the smallholder sector because of inbreeding, loss of indigenous knowledge (IK) among herbalists and the elderly, and limited nutrition $[7,72]$. The situation is aggravated by the lack of extension and veterinary services, inadequate infrastructure for storage of vaccines and medicine, poor road conditions, with some transport operators either refusing to drive on these roads or charging high prices [73]. As is the case for Malawi, rural artisanal groups such as village farmer technicians, para-veterinary practitioners, lead farmers, and farmer extension workers have been trained to provide animal healthcare and extension services [74].

Government and civic society organisations should provide support for the development of community-based healthcare services such as mobile cost recovery drug boxes [46,74] to complement farmer efforts. This could make significant contributions to the sustainable use of cattle genetic 
resources in the region by reducing health related losses and costs. Randolph et al. [75] suggested that partnership between community animal health workers and professionals could be successful in affording the much needed basic health and veterinary services to cattle in marginalised and remote communities. Ethno-veterinary medicines should also be evaluated and IK strengthened to complement the conventional control methods [37,76]. Bioprospecting of indigenous multipurpose trees as ethno-medicine, feed supplements, and meat biopreservatives can simultaneously curb animal health and nutrition challenges as well as meat spoilage problems experienced by smallholder farmers [62].

\subsection{Marketing Strategies for Cattle Products}

Sustainable use of indigenous cattle genetic resources is an important component in meeting the current and future demand for cattle products. Overall, smallholder farmers operate under dismal market conditions, and are faced with high transactional costs. This significantly reduces their incentive for market participation $[77,78]$. The marketing of products from indigenous cattle remains fragmented as the smallholder sector is insufficiently structured. Poor road conditions and inadequate marketing infrastructure further impedes access to markets by smallholder cattle producers [74,78]. This shortfall in terms of the delivery of infrastructure services is attributable to, among others, biased and flawed priorities, poor management, and resource scarcity [79]. Exploring new markets, expanding existing ones, and improving market access by smallholder farmers may contribute towards sustainable use of the local breeds. In addition, introducing community-based microfinance (i.e., micro-credit, micro-savings, and micro-insurance) co-operatives, which would enable smallholder farmers to lend and/or invest money in groups, gain some bargaining power, and enjoy the benefits of economies of scale, could be of importance for sustainable use of indigenous cattle breeds $[80,81]$.

Overall, indigenous cattle breeds are ideally suited to being marketed off rangelands [1]. In that regard, development of new indigenous breed-specific product valuation systems (e.g., carcass classification system), niche products (e.g., free-range, grass-fed, organic), and value-added products (e.g., biltong, snapsticks, and droëwors) can sustainably transform their utility [1,54]. For example, beef from a rangeland-based production system, which has been successfully promoted for its unique humane and sustainable qualities under the "free-range" and/or "grass-fed" brands (http://www.grassfedsa.org/) [82] in South Africa, can be further associated with a specific indigenous breed. Similarly, PBP-fed beef from specific indigenous breeds can be marketed based on their distinctive ecological benefits, nutritional, and organoleptic attributes [62]. To this end, information on credence (e.g., breed and production system) and experience (e.g., flavour and texture) attributes of beef should occupy prominent positions in the labelling, as they play important roles at the moment of choice [83]. The unique product attributes of indigenous cattle, including multi-coloured hides and organic beef raised with little or no acaricides, anthelmintics, growth enhancers, and inorganic feed supplements, offer opportunities for niche marketing and sustainable food production in smallholder areas. Niche production may experience advancements in the future, and certain customer segments would be willing to pay a premium for such products [84].

Commercialisation of indigenous breeds is likely to lead to more advanced production systems, which are based on comparative advantage [85]. The advantages of commercialising indigenous cattle include provision of non-market, credence goods and services of cattle (i.e., draught power, cultural heritage, bio-recycling, ecotourism, and education). Increasing the profitability of beef production by enhancing the value of market, non-market, credence goods and services, especially if accompanied by suitable quantification and valuation frameworks of the non-market and credence goods and services could sustainably improve the use of indigenous cattle [32].

\subsection{Women and Youth Empowerment Strategies}

In the SADC, cattle farming labour force is dominated by women and youth [76,86]. Yet, women do not generally own cattle, and face cultural and institutional barriers to access and control the benefits 
of cattle farming [87]. In addition, decision making about revenue and benefits of cattle farming are dominated by elderly men [88]. Worse still, women and youth are disproportionally affected by hunger and malnourishment [86]. Women and youth empowerment is one strategy which has been shown to improve household food and nutrition security [88,89]. This is because women spend more of their income earnings on the household food and nutrition compared to men [88]. In that regard, an engendered approach that takes note of local circumstances, existing adaptive IK, and resilient technologies for use as a bulwark for adaptation against the effects of a changing and increasingly variable climate [90] could result in sustainable use of indigenous cattle. The youth generally lack interest in cattle farming as they consider it dirty, laborious, and unrewarding [91]. This could indicate the absence of dedicated and motivated heirs to advance sustainable use of cattle genetic resources in the future [92]. In that regard, it is important to empower and integrate women and youth into existing and future projects on sustainable utilisation of cattle genetic resources. For example, in the current NAMC custom feeding and Nguni projects in South Africa, women and youth can be organised into co-operatives, and given cattle, access to and control over cattle farming benefits, and other productive resources such as land, training, education, extension, and financial services and technology, particularly information and communications technologies [81]. The use of information and communication technology has greatly transformed the way agricultural extension operates, especially in Africa, where the road infrastructure tends to limit the link between the farmer and service providers (i.e., extension officers) [93].

Integration of youth can also be done by fusing of the IK on cattle farming held by the elderly men with the innovation skills of the youth as a way of adapting indigenous cattle breeds to new challenges and keeping them in line with new innovations and changes in time. Thus, IK should be integrated into strategic plans for sustainable use of indigenous cattle genetic resources if communities are to build climate resilient, sustainable food and income secure livelihoods. Capacitating women and youth through community-based training programs can provide significant impetus to the sustainable use of cattle genetic resources. For example, training programs for rural artisanal groups could be dedicated to the women and youth as a form of gender and youth empowerment. This could act as a safety net for food security in the face of severe climate fluctuations, especially among the women- and youth-headed households, which are considered highly vulnerable to changes in climate.

\subsection{Institutional Support Strategies}

Legislation and policy interventions are necessary to enhance the functioning of input and output markets, improve service provision and development of infrastructure so that the goal of structural transformation can be achieved smoothly [85]. In addition, planned training and capacity building initiatives at the community level, and from primary to tertiary education levels, are important in ensuring sustainable use of animal genetic resources [94]. Such training and capacity-building activities enhance suitable corporative-building, leadership and skills that would create and support an enabling environment for sustainable use of animal genetic resources. If the level of education among smallholder farmers is improved, this could promote effective management with regards to their farming operations. Mapiye et al. [81] argues that the level of farmers' education influences their perceptions, and hence understanding of various challenges of the cattle enterprise. To effectively implement the suggested strategies for sustainable use of indigenous cattle breeds, partnerships and collaboration among stakeholders (Figure 1) in the preparation and implementation of a strategic long-term plan is essential. Stakeholder participation is important because cattle genetic resources are commonly managed as a common good involving private and public interests [52]. Stakeholder involvement includes participation in animal-, marketing-, and policy-level activities. Such stakeholders include farmers and farmer organisations, breeders and breed societies, associations or cooperatives, community-based organisations, commercial companies (i.e., input suppliers, abattoir operators, meat processors, and retailers), public or private research institutions, public services (government, policymakers, veterinary, and extension services), civil society organisations, and international donors (Figure 1). There might be 
resistance from key stakeholders such as producers and breed societies whose livelihoods are based on non-indigenous breeds. However, the two systems should complement each other by using indigenous breeds in commercial crossbreeding programs. For example, Sanga cattle have been used as dam lines in crossbreeding programs in order to meet the requirements of the commercial sector [34]. All stakeholders should work together to achieve a common goal, but with the producer objectives at the core of the system (Figure 1). The institutions and resulting collaborations and networks form avenues to reduce high transaction costs involved in the smallholder sector. Overall, it is important to ensure that all the stakeholders and necessary production technologies (e.g., breeding, feeding, and healthcare technologies) are appropriately coordinated and linked to improved infrastructure and institutional arrangements for marketing, input supply, and financial supply [95,96]. A systems approach to these issues, with proper funding by the stakeholders, may lead to sustainable utilisation of cattle genetic resources.

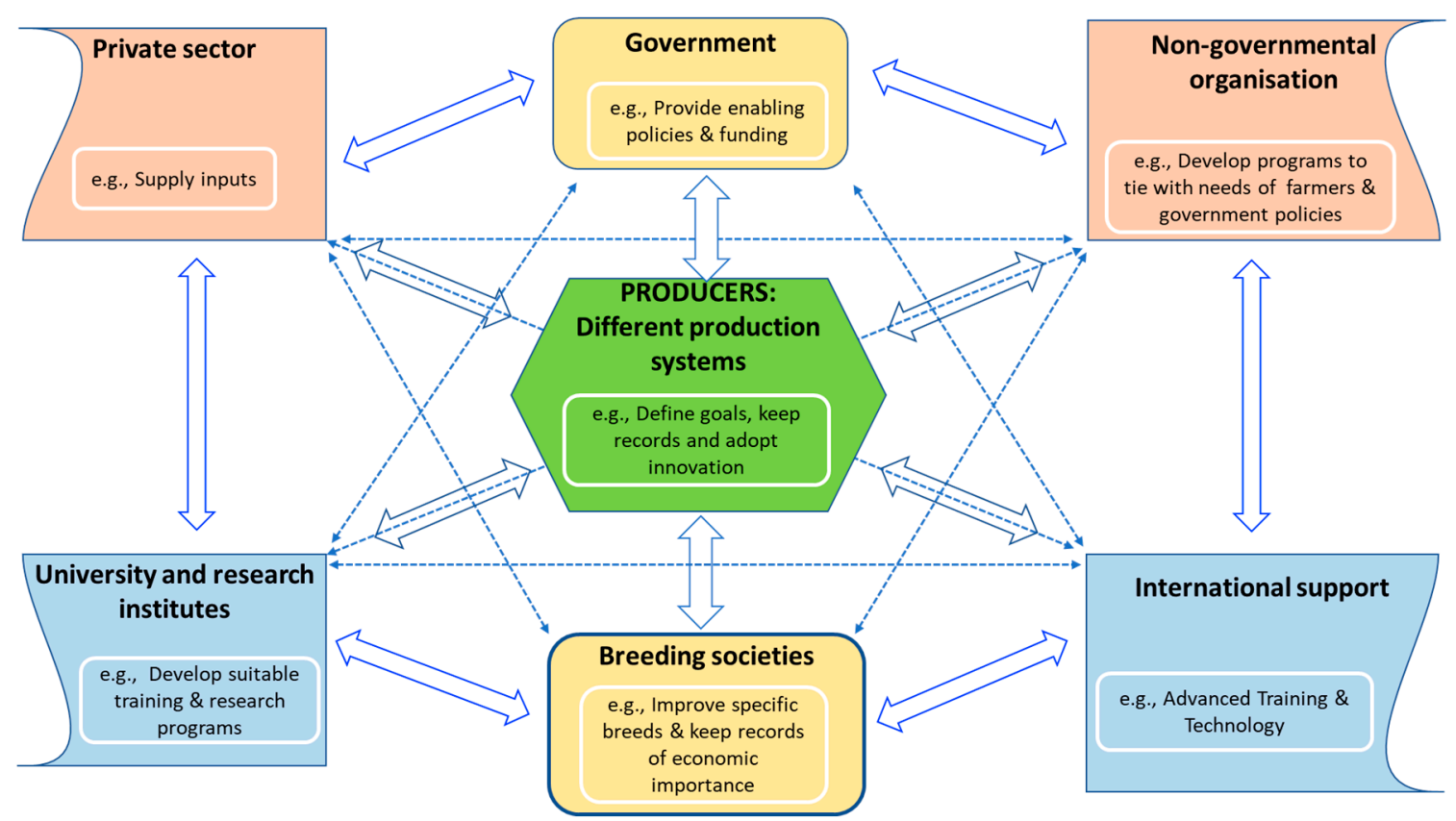

Figure 1. Stakeholders' approach for sustainable use of cattle genetic resources in the SADC. Adapted from Ibeagha-Awemu et al. [41].

\section{Conclusions}

A combination of underutilisation of indigenous breeds, strong focus on high-output breeds, and specialised production systems in the SADC region have led to a considerable decline in the diversity of indigenous cattle genetic resources. Key strategies to maintain diversity and ensure sustainable use of indigenous cattle breeds should include genetic improvement programmes targeting unique productive and adaptive traits; increased nutrition, healthcare, marketing, and infrastructure opportunities; integration and empowerment of women and youth; and institution of appropriate capacity building, regulatory, and policy frameworks.

Author Contributions: Conceptualisation, C.M. and K.D.; Writing original draft, C.M. and O.C.C.; Editorial inputs, M.C. and K.D. All authors read and approved the final manuscript.

Funding: South African Research Chairs Initiative (SARChI) partly funded by the South African Department of Science and Technology (DST) (UID number: 84633), as administered by the National Research Foundation (NRF) of South Africa for providing funds for the research.

Acknowledgments: O.C.C. acknowledges Consolidoc Fellowship from Meat Science SARChI partly funded by the DST, South Africa (UID number: 84633), as administered by the NRF.

Conflicts of Interest: Authors declare no conflict of interest. 


\section{References}

1. Chingala, G.; Raffrenato, E.; Dzama, K.; Hoffman, L.C.; Mapiye, C. Towards a regional beef carcass classification system for Southern Africa Beef production and marketing systems in Southern Africa. S. Afr. J. Anim. Sci. 2017, 47, 408-423. [CrossRef]

2. Frisch, J.E.; Drinkwater, R.; Harrison, B.; Johnson, S. Classification of the southern African sanga and East African shorthorned zebu. Anim. Genet. 1997, 28, 77-83. [CrossRef] [PubMed]

3. Mwai, O.; Hanotte, O.; Kwon, Y.J.; Cho, S. African indigenous cattle: Unique genetic resources in a rapidly changing world. Asian Australas. J. Anim. Sci. 2015, 28, 911-921. [CrossRef] [PubMed]

4. Lashmar, S.F.; Muchadeyi, F.C.; Visser, C. Genotype imputation as a cost-saving genomic strategy for South African Sanga cattle: A review. S. Afr. J. Anim. Sci. 2019, 49, 263-280. [CrossRef]

5. Rege, J.E.O.; Marshall, K.; Notenbaert, A.; Ojango, J.M.K.; Okeyo, A.M. Pro-poor animal improvement and breeding-What can science do? Livest. Sci. 2011, 136, 15-28. [CrossRef]

6. Muchenje, V.; Hugo, A.; Dzama, K.; Chimonyo, M.; Strydom, P.E.; Raats, J.G. Cholesterol levels and fatty acid profiles of beef from three cattle breeds raised on natural pasture. J. Food Compos. Anal. 2009, 22, 354-358. [CrossRef]

7. Nyamushamba, G.B.; Mapiye, C.; Tada, O.; Halimani, T.E.; Muchenje, V. Conservation of indigenous cattle genetic resources in Southern Africa's smallholder areas: Turning threats into opportunities-A review. Asian Australas. J. Anim. Sci. 2017, 30, 603-621. [CrossRef] [PubMed]

8. Nguni Cattle Breeders' Society Galleries. Available online: http://www.nguni.co.za/Gallery-General.htm (accessed on 25 September 2019).

9. Leisure Lounge Nguni. Available online: https://www.leisurelounge.co.za/product/nguni-ottoman/ (accessed on 25 September 2019).

10. Rose \& Fitzgerald Co. Ankole Horn Tumbler Sets; Rose \& Fitzgerald Co.: Kampala, Uganda. Available online: https://shop.roseandfitzgerald.com/products/ankole-horn-whisky-tumbler-set-light (accessed on 25 September 2019).

11. OboraLux LLC. The Ankole Collection. Available online: https://www.oboralux.com/collections/the-ankolecollection (accessed on 25 September 2019).

12. Felius, M.; Koolmees, P.A.; Theunissen, B.; Lenstra, J.A. On the breeds of cattle-Historic and current classifications. Diversity 2011, 3, 660-692. [CrossRef]

13. Van Marle-Köster, E.; Visser, C. Genetic improvement in South African livestock: Can genomics bridge the gap between the developed and developing sectors? Front. Genet. 2018, 9, 331. [CrossRef] [PubMed]

14. Rege, J.E.O. The State of African Cattle Genetic Resources I. Classification Framework and Identification of Threatened and Extinct Breeds; Cambridge University Press: Cambridge, UK, 1999.

15. Zwane, A.A.; Maiwashe, A.; Makgahlela, M.L.; Choudhury, A.; Taylor, J.F.; van Marle-Köster, E. Genome-wide identification of breed-informative single-nucleotide polymorphisms in three South African indigenous cattle breeds. S. Afr. J. Anim. Sci. 2016, 46, 302-312.

16. Gwakisa, P.S.; Kemp, S.J.; Teale, A.J. Characterization of Zebu cattle breeds in Tanzania using random amplified polymorphic DNA markers. Anim. Genet. 1994, 25, 89-94. [CrossRef] [PubMed]

17. Sanarana, Y.; Visser, C.; Bosman, L.; Nephawe, K.; Maiwashe, A.; van Marle-Köster, E. Genetic diversity in South African Nguni cattle ecotypes based on microsatellite markers. Trop. Anim. Health Prod. 2016, 48, 379-385. [CrossRef] [PubMed]

18. Kotze, A.; Harun, M.; Otto, F.; Van Der Bank, F.H. Genetic relationships between three indigenous cattle breeds in Mozambique. S. Afr. J. Anim. Sci. 2000, 30, 92-97. [CrossRef]

19. Bessa, I.; Pinheiro, I.; Matola, M.; Dzama, K.; Rocha, A.; Alexandrino, P. Genetic diversity and relationships among indigenous Mozambican cattle breeds. S. Afr. J. Anim. Sci. 2009, 39, 61-72.

20. Makina, S.O.; Muchadeyi, F.C.; van Marle-Köster, E.; MacNeil, M.D.; Maiwashe, A. Genetic diversity and population structure among six cattle breeds in South Africa using a whole genome SNP panel. Front. Genet. 2014, 5, 333. [CrossRef] [PubMed]

21. Pienaar, L.; Grobler, J.P.; Neser, F.W.C.; Scholtz, M.M.; Swart, H.; Ehlers, K.; Marx, M. Genetic diversity in selected stud and commercial herds of the Afrikaner cattle breed. S. Afr. J. Anim. Sci. 2014, 44, S80-S84.

22. Abin, S.; Theron, H.E.; Van Marle-Köster, E. Population structure and genetic trends for indigenous African beef cattle breeds in South Africa. S. Afr. J. Anim. Sci. 2016, 46, 152-156. [CrossRef] 
23. Gororo, E.; Makuza, S.M.; Chatiza, F.P.; Chidzwondo, F.; Sanyika, T.W. Genetic diversity in Zimbabwean Sanga cattle breeds using microsatellite markers. S. Afr. J. Anim. Sci. 2018, 48, 128-141. [CrossRef]

24. Van Marle-Köster, E.; Visser, C. Genomics for the advancement of livestock production: A South African perspective. S. Afr. J. Anim. Sci. 2018, 48, 808-817. [CrossRef]

25. Kuehn, L.A.; Keele, J.W.; Bennett, G.L.; McDaneld, T.G.; Smith, T.P.L.; Snelling, W.M.; Sonstegard, T.S.; Thallman, R.M. Predicting breed composition using breed frequencies of 50,000 markers from the US Meat Animal Research Center 2000 Bull Project. J. Anim. Sci. 2011, 89, 1742-1750. [CrossRef] [PubMed]

26. Solti, L.; Crichton, E.G.; Loskutoff, N.M.; Cseh, S. Economic and ecological importance of indigenous livestock and the application of assisted reproduction to their preservation. Theriogenology 2000, 53, 149-162. [CrossRef]

27. FAO. The State of the World's Animal Genetic Resources for Food and Agriculture; Rischkowsky, B., Pilling, D., Eds.; Commission on Genetic Resources for Food and Agriculture, Food and Agriculture Organization of the United Nations: Rome, Italy, 2007; ISBN 9789251057629.

28. ILRI (International Livestock Research Institute). Climate, Livestock and Poverty: Challenges at the Interface; Corporate Report 2008-9; ILRI: Nairobi, Kenya, 2009.

29. Taberlet, P.; Coissac, E.; Pansu, J.; Pompanon, F. Conservation genetics of cattle, sheep, and goats. C. R. Biol. 2011, 334, 247-254. [CrossRef] [PubMed]

30. Reist-Marti, S.B.; Simianer, H.; Gibson, J.; Hanotte, O.; Rege, J.E.O. Weitzman's approach and conservation of breed diversity: An application to African cattle breeds. Conserv. Biol. 2003, 17, 1299-1311. [CrossRef]

31. Wainwright, W.; Glenk, K.; Akaichi, F.; Moran, D. Conservation contracts for supplying Farm Animal Genetic Resources (FAnGR) conservation services in Romania. Livest. Sci. 2019, 224, 1-9. [CrossRef]

32. Marsoner, T.; Egarter Vigl, L.; Manck, F.; Jaritz, G.; Tappeiner, U.; Tasser, E. Indigenous livestock breeds as indicators for cultural ecosystem services: A spatial analysis within the Alpine Space. Ecol. Indic. 2018, 94, 55-63. [CrossRef]

33. Wollny, C.B.A. The need to conserve farm animal genetic resources in Africa: Should policy makers be concerned? Ecol. Econ. 2003, 45, 341-351. [CrossRef]

34. Scholtz, M.M.; Bester, J.; Mamabolo, J.M.; Ramsay, K.A. Results of the national cattle survey undertaken in South Africa, with emphasis on beef. Appl. Anim. Husb. Rural Dev. 2008, 1, 1-9.

35. Scholtz, M.M.; Maiwashe, A.; Neser, F.W.C.; Theunissen, A.; Olivier, W.J.; Mokolobate, M.C.; Hendriks, J. Livestock breeding for sustainability to mitigate global warming, with the emphasis on developing countries. S. Afr. J. Anim. Sci. 2013, 43, 269-281. [CrossRef]

36. Camara, Y.; Sow, F.; Govoeyi, B.; Moula, N.; Sissokho, M.M.; Antoine-Moussiaux, N. Stakeholder involvement in cattle-breeding program in developing countries: A Delphi survey. Livest. Sci. 2019, 228, 127-135. [CrossRef]

37. Hoffmann, I. Ecosystem Servicies Provided by Livestock Species and Breeds, with Special Consideration to the Contributions of Small-Scale Livestock Keepers and Pastoralists; FAO Commission on Genetic Resources for Food and Agriculture: Rome, Italy, 2014.

38. Marshall, K.; Gibson, J.P.; Mwai, O.; Mwacharo, J.M.; Haile, A.; Getachew, T.; Mrode, R.; Kemp, S.J. Livestock genomics for developing countries-African examples in practice. Front. Genet. 2019, 10, 297. [CrossRef] [PubMed]

39. Lebbie, S.H.B.; Ramsay, K. A perspective on conservation and management of small ruminant genetic resources in the sub-Saharan Africa. Small Rumin. Res. 1999, 34, 231-247. [CrossRef]

40. Pienaar, L.; Grobler, J.P.; Scholtz, M.M.; Swart, H.; Ehlers, K.; Marx, M.; MacNeil, M.D.; Neser, F.W.C. Genetic diversity of Afrikaner cattle in southern Africa. Trop. Anim. Health Prod. 2018, 50, 399-404. [CrossRef] [PubMed]

41. Ibeagha-Awemu, E.M.; Peters, S.O.; Bemji, M.N.; Adeleke, M.A.; Do, D.N. Leveraging available resources and stakeholder involvement for improved productivity of African livestock in the era of genomic breeding. Front. Genet. 2019, 10, 357. [CrossRef] [PubMed]

42. UN. Convention on Biological Diversity. Available online: https://www.cbd.int/doc/legal/cbd-en.pdf (accessed on 16 July 2019).

43. Getachew, T.; Haile, A.; Rischkowsky, B. How to tailor community based breeding programs for small ruminants to pastoral production systems. In Proceedings of the World Congress on Genetics Applied to Livestock Production, Auckland, New Zealand, 11-16 February 2018; Volume 11, p. 858. 
44. Wurzinger, M.; Sölkner, J.; Iñiguez, L. Important aspects and limitations in considering community-based breeding programs for low-input smallholder livestock systems. Small Rumin. Res. 2011, 98, 170-175. [CrossRef]

45. Gowane, G.R.; Kumar, A.; Nimbkar, C. Challenges and opportunities to livestock breeding programmes in India. J. Anim. Breed. Genet. 2019, 136, 329-338. [CrossRef] [PubMed]

46. Nimbkar, C.; Gibson, J.; Okeyo, M.; Boettcher, P.; Soelkner, J. Sustainable use and genetic improvement. Anim. Genet. Resour. Inf. 2008, 42, 49-65. [CrossRef]

47. Eriksson, S.; Jonas, E.; Rydhmer, L.; Röcklinsberg, H. Invited review: Breeding and ethical perspectives on genetically modified and genome edited cattle. J. Dairy Sci. 2018, 101, 1-17. [CrossRef] [PubMed]

48. Tait-Burkard, C.; Doeschl-Wilson, A.; McGrew, M.J.; Archibald, A.L.; Sang, H.M.; Houston, R.D.; Whitelaw, C.B.; Watson, M. Livestock 2.0-Genome editing for fitter, healthier, and more productive farmed animals. Genome Biol. 2018, 19, 204. [CrossRef] [PubMed]

49. Van Eenennaam, A.L. Application of genome editing in farm animals: Cattle. Transgenic Res. 2019, $28,93-100$. [CrossRef] [PubMed]

50. Mueller, M.L.; Cole, J.B.; Sonstegard, T.S.; Van Eenennaam, A.L. Comparison of gene editing versus conventional breeding to introgress the POLLED allele into the US dairy cattle population. J. Dairy Sci. 2019, 102, 4215-4226. [CrossRef] [PubMed]

51. Paiva, S.R.; McManus, C.M.; Blackburn, H. Conservation of animal genetic resources-A new tact. Livest. Sci. 2016, 193, 32-38. [CrossRef]

52. Leroy, G.; Baumung, R.; Notter, D.; Verrier, E.; Wurzinger, M.; Scherf, B. Stakeholder involvement and the management of animal genetic resources across the world. Livest. Sci. 2017, 198, 120-128. [CrossRef]

53. Kohler-Rollerfson, I. Farm Animal Genetic Resources: Safeguading national Asses for Food Security and Trade; GTZ, FAO, CTA: Eschborn, Germany, 2004.

54. Pundir, R.K.; Niranjan, S.K.; Behl, R. Sustainable Utilization of Indigenous Animal Genetic Resources of India; National Bureau of Animal Genetic Resources: Karnal, Haryana, India, 2013.

55. Davis, K.E.; Terblanché, S.E. Challenges facing the agricultural extension landscape in South Africa, Quo Vadis? S. Afr. J. Agric. Ext. 2016, 44, 231-247. [CrossRef]

56. Mapiye, C.; Chimonyo, M.; Marufu, M.C.; Dzama, K. Utility of Acacia karroo for beef production in Southern African smallholder farming systems: A review. Anim. Feed Sci. Technol. 2011, 164, 135-146. [CrossRef]

57. Fernández-Giménez, M.E.; Batkhishig, B.; Batbuyan, B.; Ulambayar, T. Lessons from the Dzud: Community-based rangeland management increases the adaptive capacity of Mongolian herders to winter disasters. World Dev. 2015, 68, 48-65. [CrossRef]

58. Chan, J.M.; Day, P.; Feely, J.; Thompson, R.; Little, K.M.; Norris, C.H. Acacia mearnsii industry overview: Current status, key research and development issues. South. For. 2015, 77, 19-30. [CrossRef]

59. Chingala, G.; Raffrenato, E.; Dzama, K.; Hoffman, L.C.; Mapiye, C. Carcass and meat quality attributes of Malawi Zebu steers fed Vachellia polyacantha leaves or Adansonia digitata seed as alternative protein sources to Glycine max. S. Afr. J. Anim. Sci. 2019, 49, 395-402. [CrossRef]

60. Mapiye, C.; Chimonyo, M.; Dzama, K.; Strydom, P.E.; Muchenje, V.; Marufu, M.C. Nutritional status, growth performance and carcass characteristics of Nguni steers supplemented with Acacia karroo leaf-meal. Livest. Sci. 2009, 126, 206-214. [CrossRef]

61. Marandure, T.; Bennett, J.; Dzama, K.; Gwiriri, L.C.; Bangani, N.; Mapiye, C. Envisioning more effective delivery of custom feeding programs using participatory approaches: Lessons from Eastern Cape Province, South Africa. Outlook Agric. 2019, 48, 157-166. [CrossRef]

62. Salami, S.A.; Luciano, G.; O'Grady, M.N.; Biondi, L.; Newbold, C.J.; Kerry, J.P.; Priolo, A. Sustainability of feeding plant by-products: A review of the implications for ruminant meat production. Anim. Feed Sci. Technol. 2019, 251, 37-55. [CrossRef]

63. Wadhwa, M.; Bakshi, M.P.; Makkar, H.P.S. Waste to worth: Fruit wastes and by-products as animal feed. CAB Rev. 2015, 10, 1-26. [CrossRef]

64. Tayengwa, T.; Mapiye, C. Citrus and winery wastes: Promising dietary supplements for sustainable ruminant animal nutrition, health, production, and meat quality. Sustainability 2018, 10, 3718. [CrossRef]

65. Kadzere, C.T. Environmentally smart animal agriculture and integrated advisory services ameliorate the negative effects of climate change on production. S. Afr. J. Anim. Sci. 2018, 48, 842-857. [CrossRef] 
66. Svinurai, W.; Mapanda, F.; Sithole, D.; Moyo, E.N.; Ndidzano, K.; Tsiga, A.; Zhakata, W. Enteric methane emissions and their response to agro-ecological and livestock production systems dynamics in Zimbabwe. Sci. Total Environ. 2018, 616-617, 710-719. [CrossRef] [PubMed]

67. Shabtay, A. Adaptive traits of indigenous cattle breeds: The Mediterranean Baladi as a case study. Meat Sci. 2015, 109, 27-39. [CrossRef] [PubMed]

68. Naumann, H.D.; Tedeschi, L.O.; Zeller, W.E.; Huntley, N.F. The role of condensed tannins in ruminant animal production: Advances, limitations and future directions. Rev. Bras. Zootec. 2017, 46, 929-949. [CrossRef]

69. Molina-Botero, I.C.; Arroyave-Jaramillo, J.; Valencia-Salazar, S.; Barahona-Rosales, R.; Aguilar-Pérez, C.F.; Ayala Burgos, A.; Arango, J.; Ku-Vera, J.C. Effects of tannins and saponins contained in foliage of Gliricidia sepium and pods of Enterolobium cyclocarpum on fermentation, methane emissions and rumen microbial population in crossbred heifers. Anim. Feed Sci. Technol. 2019, 251,1-11. [CrossRef]

70. Ugbogu, E.A.; Elghandour, M.M.M.Y.; Ikpeazu, V.O.; Buendía, G.R.; Molina, O.M.; Arunsi, U.O.; Emmanuel, O.; Salem, A.Z.M. The potential impacts of dietary plant natural products on the sustainable mitigation of methane emission from livestock farming. J. Clean. Prod. 2019, 213, 915-925. [CrossRef]

71. Sapkota, T.B.; Vetter, S.H.; Jat, M.L.; Sirohi, S.; Shirsath, P.B.; Singh, R.; Jat, H.S.; Smith, P.; Hillier, J.; Stirling, C.M. Cost-effective opportunities for climate change mitigation in Indian agriculture. Sci. Total Environ. 2019, 655, 1342-1354. [CrossRef] [PubMed]

72. Mapiye, C.; Chimonyo, M.; Dzama, K.; Raats, J.G.; Mapekula, M. Opportunities for improving Nguni cattle production in the smallholder farming systems of South Africa. Livest. Sci. 2009, 124, 196-204. [CrossRef]

73. Chigumira, E. Political ecology of agrarian transformation: The nexus of mining and agriculture in Sanyati District, Zimbabwe. J. Rural Stud. 2018, 61, 265-276. [CrossRef]

74. Chagunda, M.G.G.; Mwangwela, A.; Mumba, C.; Anjos Dos, F.; Kawonga, B.S.; Hopkins, R.; Chiwona-Kartun, L. Assessing and managing intensification in smallholder dairy systems for food and nutrition security in Sub-Saharan Africa. Reg. Environ. Chang. 2016, 16, 2257-2267. [CrossRef]

75. Randolph, T.F.; Schelling, E.; Grace, D.; Nicholson, C.F.; Leroy, J.L.; Cole, D.C.; Demment, M.W.; Omore, A.; Zinsstag, J.; Ruel, M. Invited review: Role of livestock in human nutrition and health for poverty reduction in developing countries. J. Anim. Sci. 2007, 85, 2788-2800. [CrossRef] [PubMed]

76. FAO. Invisible Guardians_Women Manage Livestock Diversity; FAO: Rome, Italy, 2012.

77. Chamberlin, J.; Jayne, T.S. Unpacking the meaning of "market access": Evidence from rural Kenya. World Dev. 2013, 41, 245-264. [CrossRef]

78. Nkadimeng, M.V. Determinants of Market Participation and Profitability for Smallholder Nguni Livestock Farmers: Implications for Food Security and Livelihoods in the Limpopo Province; University of Limpopo: Polokwane, South Africa, 2019.

79. Makhura, M.N.; Wasike, W.S.K. Patterns of access to rural service infrastructure: The case of farming households in Limpopo Province. Agrekon 2003, 42, 129-143. [CrossRef]

80. Pérez Perdomo, S.A.; Farrow, A.; Trienekens, J.H.; Omta, S.W.F. Stakeholder roles for fostering ambidexterity in Sub-Saharan African agricultural netchains for the emergence of multi-stakeholder cooperatives. J. Chain Netw. Sci. 2016, 16, 59-82. [CrossRef]

81. Mapiye, O.; Makombe, G.; Mapiye, C.; Dzama, K. Limitations and prospects of improving beef cattle production in the smallholder sector: A case of Limpopo Province, South Africa. Trop. Anim. Health Prod. 2018, 50, 1711-1725. [CrossRef] [PubMed]

82. Grassfed, S.A. The Home of Trusted Grassfed Meat. Available online: http://www.grassfedsa.org/ (accessed on 25 September 2019).

83. Resano, H.; Sanjuán, A.I. Exploring the role of mountain origin and autochthonous breed on urban consumers' acceptability. Sustainability 2018, 10, 4423. [CrossRef]

84. Argemí-Armengol, I.; Villalba, D.; Tor, M.; Pérez-Santaescolástica, C.; Purriños, L.; Manuel Lorenzo, J.; Álvarez-Rodríguez, J. The extent to which genetics and lean grade affect fatty acid profiles and volatile compounds in organic pork. PeerJ 2019, 7, e7322. [CrossRef] [PubMed]

85. Abdullah; Rabbi, F.; Ahamad, R.; Ali, S.; Chandio, A.A.; Ahmad, W.; Ilyas, A.; Din, I.U. Determinants of commercialization and its impact on the welfare of smallholder rice farmers by using Heckman's two-stage approach. J. Saudi Soc. Agric. Sci. 2019, 18, 224-233.

86. Verhart, N.; van den Wijngaart, A.; Dhamankar, M.; Danielsen, K. Bringing Agriculture and Nutrition Together; Royal Tropical Institute: Amsterdam, The Netherlands, 2015. 
87. Must, E.; Hovorka, J. 'What's in a Name': Implications of women's cattle ownership for transformative gender mainstreaming in Botswana. J. Gend. Agric. Food Secur. 2017, 2, 84-105.

88. Njuki, J.; Distefano, F. Report on the FAO-ILRI training workshop. In Understanding and Integrating Gender in Livestock Projects and Programs; FAO-ILRI: Addis Ababa, Ethiopia, 2011.

89. Galiè, A.; Teufel, N.; Girard, A.W.; Baltenweck, I.; Dominguez-Salas, P.; Price, M.J.; Jones, R.; Lukuyu, B.; Korir, L.; Raskind, I.G.; et al. Women's empowerment, food security and nutrition of pastoral communities in Tanzania. Glob. Food Secur. 2019, 23, 125-134. [CrossRef]

90. Chanza, N.; De Wit, A. Enhancing climate governance through indigenous knowledge: Case in sustainability science. S. Afr. J. Sci. 2016, 112, 112. [CrossRef]

91. Swarts, M.B.; Aliber, M. The "youth and agriculture" problem: Implications for rangeland development. Afr. J. Range Forage Sci. 2013, 30, 23-27. [CrossRef]

92. Bernués, A.; Ruiz, R.; Olaizola, A.; Villalba, D.; Casasús, I. Sustainability of pasture-based livestock farming systems in the European Mediterranean context: Synergies and trade-offs. Livest. Sci. 2011, 139, 44-57. [CrossRef]

93. Mwesigwa, E.; Tulinayo, F.P.; Mirembe, D.P. Enhancing Agricultural Knowledge Sharing Among Smallholder Farmers in Uganda: An Evaluation of Mobile and Web Technologies; Makerere University: Kampala Uganda, 2016; Volume 14.

94. Ojango, J.; Malmfors, B.; Okeyo, A.M.; Philipsson, J. Capacity building for sustainable use of animal genetic resources in developing countries. Appl. Anim. Husb. Rural Dev. 2009, 2, $23-26$.

95. McDermott, J.J.; Staal, S.J.; Freeman, H.A.; Herrero, M.; Van de Steeg, J.A. Sustaining intensification of smallholder livestock systems in the tropics. Livest. Sci. 2010, 130, 95-109. [CrossRef]

96. Tarawali, S.; Herrero, M.; Descheemaeker, K.; Grings, E.; Blümmel, M. Pathways for sustainable development of mixed crop livestock systems: Taking a livestock and pro-poor approach. Livest. Sci. 2011, 139, 11-21. [CrossRef]

(C) 2019 by the authors. Licensee MDPI, Basel, Switzerland. This article is an open access article distributed under the terms and conditions of the Creative Commons Attribution (CC BY) license (http://creativecommons.org/licenses/by/4.0/). 